\title{
Habitações Operárias: evolução das imagens de representação
}

\section{Daniela Ketzer Milano}

Mestrado: História Ibero Americana - Faculdade de Filosofia e Ciências Humanas da Pontifícia Universidade Católica do Rio Grande do Sul

\section{Resumo}

O surgimento das cidades ao redor das fábricas a partir da Revolução Industrial acarretou em um acelerado processo de urbanização devido a necessidade por moradias por parte do contingente desenfreado de imigrantesoperários vindos do campo. A precariedade das condições habitacionais fez surgir políticas públicas na tentativa de resolver tais questões, para tanto, foram criadas as comissões de inquérito, o jornalismo de denúncia e os relatórios médico-sanitários. O presente artigo tem o objetivo, analisar os tipos de imagens utilizadas ao longo da história, que constituíram a referência de base para as proposições de reforma urbana e os programas de habitação social.

Palavras-chave: habitação operária. Revolução Industrial. imagens.

\section{Abstract}

The sprouting of the cities around of the plants from the Industrial Revolution it caused one sped up urbanization process had the necessity for housings on the part of the wild contingent of come immigrant-laborers of the field. The precariousness of the habitacionais conditions it made to appear public politics in the attempt to decide such questions, for in such a way, the inquiry commissions had been created, the doctor sanitary journalism of denunciation and reports. The present article has objective, to analyze the types of images used throughout history, that they had constituted the reference of base for the proposals of urban reform and the programs of social habitation.

Key words: laboring habitation. Industrial Revolution. images.

A Revolução Industrial ocorrida na Inglaterra, integra o conjunto das "Revoluções Burguesas" do século XVIII, responsáveis pela crise do Antigo Regime, na passagem do capitalismo comercial para o industrial. Os outros dois movimentos que a acompanham são a Independência dos Estados Unidos e a 
Revolução Francesa, que sob influência dos princípios iluministas assinalam a transição da Idade Moderna para a Contemporânea.

Em seu sentido mais pragmático, a Revolução Industrial significou a substituição da ferramenta pela máquina, e contribuiu para consolidar o capitalismo como modo de produção dominante. Esse momento revolucionário, de passagem da energia humana para motriz, é o ponto culminante de uma evolução tecnológica, social, e econômica, que vinha se processando na Europa desde a Baixa Idade Média.

A substituição das ferramentas pelas máquinas, e do modo de produção doméstico pelo fabril, bem como a evolução tecnológica e a busca por novas fontes de energias, fizeram crescer o número de estabelecimentos industriais, e conseqüentemente, de operários vindos do meio rural para suprir a grande demanda de mão de obra necessária para a indústria. Sobre a redistribuição dos habitantes no território, Benevolo comenta:

[...] em conseqüência do aumento demográfico e das transformações da produção. Os camponeses cultivadores diretos se tornaram assalariados, ou operários da indústria, e se transferem para onde existe disponibilidade de força motriz para os estabelecimentos industriais, isto é, nas proximidades dos cursos de água...Deste modo as cidades crescem mais rapidamente que o restante do país, porque acolhem seja o aumento natural da população, seja o fluxo migratório dos campos (BENEVOLO, 2003: 551).

O grande contingente de trabalhadores que surgiram, fez nascer uma nova classe social, o proletariado. Para abrigar essa nova classe de trabalhadores, foi criado um novo modelo de complexo urbano, onde a fábrica era seu núcleo principal formador juntamente a um conjunto de estabelecimentos com intenção de dar aporte aos novos bairros operários, que surgiram para abrigar a grande demanda dessa mão-de-obra. Nas diferentes cidades européias, os primeiros bairros possuíam precárias condições para a vida humana, apresentavam grande densidade, intenso aproveitamento do terreno e ausência de espaços livres e pátios.

Na primeira metade do século XIX, os problemas da cidade industrial aparecem de forma grave e intolerável para a classe subalterna. Além da insalubridade , o congestionamento do tráfego e a "feiúra" passaram a ameaçar todas as outras classes. "Por isso, tanto os representantes das classes 
dominantes, como os representantes das classes subalternas (os radicais e os socialistas) propõe novas formas de intervenção pública" (BENEVOLO, 2003: $552)$.

A realidade das condições das habitações da classe trabalhadora inglesa deste período foram expostas por esses intelectuais, primeiramente através da literatura, como o clássico manifesto $A$ Questão da Habitação de Engels, publicada em 1845, reproduz a imagem através da escrita., conforme citado na obra de Benevolo, sobre o centro de Manchester:

[...] as ruas, mesmo as melhores, são estreitas e tortuosas, as casas sujas, velhas, em ruínas, e o aspecto das ruas laterais é absolutamente horrível [...]; são os restos da velha Manchester pré-industrial, cujos antigos habitantes se transferiram com seus descendentes, para bairros melhor construídos, deixando as casas que se tinham tornado para eles demasiadamente miseráveis (...); Mas isso ainda não é nada em comparação com as vielas e os pátios que se desdobram por trás delas, e aos quais se chega somente por meio de estreitas passagens cobertas através das quais não passam nem duas pessoas uma ao lado da outra. É difícil imaginar a desordenada mistura das casas, que troça de toda urbanística racional, o amontoado, pois estão literalmente encostadas umas as outras, pois onde quer que houvesse um pedacinho de espaço entre as construções da época precedente, continuou-se a construir e a remendar, até tirar de entre as casas a última polegada de terra livre ainda suscetível de ser utilizada (ENGELS, 1979: 565)

As áreas centrais de Paris também sofrem críticas sobre um intenso adensamento, o que tematiza as questões relativas à habitabilidade e à higiene. Conforme a descrição publicada em 1849 - pouco antes, portanto, do 20 Império e das intervenções promovidas pelo Barão de Haussmann, Chevalier descreve a situação habitacional:

Uma congestão de casas apiloadas em qualquer parte do vasto horizonte. Acima, o céu está sempre encoberto, mesmo nos dias mais belos.(...) Olhando para isto, imaginamos se esta é Paris, e, hesitamos em penetrar neste vasto dédalo onde já se acotovelam mais de um milhão de homens, onde o ar é viciado de exalações insalubres, formando uma nuvem infecta que obscurece quase por completo o sol. A maior parte das ruas desta maravilhosa Paris nada mais é senão condutos sujos e sempre úmidos de água pestilenta. Encerradas entre duas fileiras de casas, as ruas nunca são penetradas pelo sol. Uma multidão pálida e doentia transita continuamente por essas ruas, os pés nas águas que escorrem, o nariz no ar infectado e os olhos atingidos, em cada esquina, pelo lixo mais repulsivo. Nessas ruas moram os trabalhadores mais bem pagos. Também há ruelas, que não 
permitem a passagem de dois homens juntos, cloacas de imundície e de lama onde uma população enfraquecida inala cotidianamente a morte. São estas as ruas da antiga Paris, ainda intactas. A cólera flagelou-as duramente sua passagem, tanto que se esperava não estarem mais lá se esta retornasse, mas a maior parte delas ainda permanece no mesmo estado, e a doença poderá voltar (CHEVALIER, 1973: 155-156).

Em um segundo momento as descrições sobre a forma de vida precária e insalubre que o proletariado europeu vivia, passaram a ser ilustradas. O principal ilustrador de gravuras foi Gustave Doré ${ }^{1}$ que foi contratado para ilustrar o livro Londres: Uma Peregrinação, muito criticado por, supostamente, retratar apenas a pobreza da cidade. Mas apesar de todas as críticas, o livro foi um sucesso de vendagem na Inglaterra, valorizando ainda mais o seu trabalho na Europa.

A crônica registra - valendo-se de metáforas tomadas da patologia - e as gravuras de Gustave Doré, a agitação febril do trânsito em Paris ou Londres, com carruagens, carroças, montarias e pedestres em insanável convulsão. Estas imagens representam o cotidiano dos moradores dos bairros operários de Londres, onde ele tenta expressar através de suas imagens o grande aglomerado de pessoas dividindo o pouco espaço, as fumaças das fábricas em meio às casas, a ocupação dos porões, o grande número de crianças cuidando de outras crianças, as pessoas habitando em meio a animais entre outras questões.

O tom escuro e a representação em preto e branco era uma característica marcante nas obra de Doré, o que acentuava ainda mais a situação de insalubridade e deixava evidente as conseqüências dessa situação calamitosa a qual se submetia a classe operária. O surgimento de doenças epidêmicas, e o risco de alastramento de epidemias causadas pela falta de higiene e condições impróprias de moradia tornou-se uma ameaça não só para a classe operária, mas para toda a sociedade. Sobre esta questão Benevolo salienta descreve que as "[...] epidemias de cólera, que grassam a partir de 1830, e a nova mentalidade filantrópica e reformista exigem uma intervenção pública na

\footnotetext{
${ }^{1} \mathrm{O}$ artista francês Gustave Doré (1832-1883) foi um dos maiores ilustradores de todos os tempos, produziu mais de 120 obras. Era também pintor e escultor, mas suas pinturas e esculturas não tinham o mesmo sucesso que suas ilustrações. Entre as obras famosas destacam-se: A divina Comédia de Dante, Gargantua de Rabelais, Contos de Balzac, Dom Quixote de Cervantes, Paraíso Perdido de Milton, O Corvo de Edgar Allan Poe e a Bíblia.
} 
melhoria das condições higiênicas dos velhos e dos novos aglomerados urbanos" (BENEVOLO, 1995: 184).

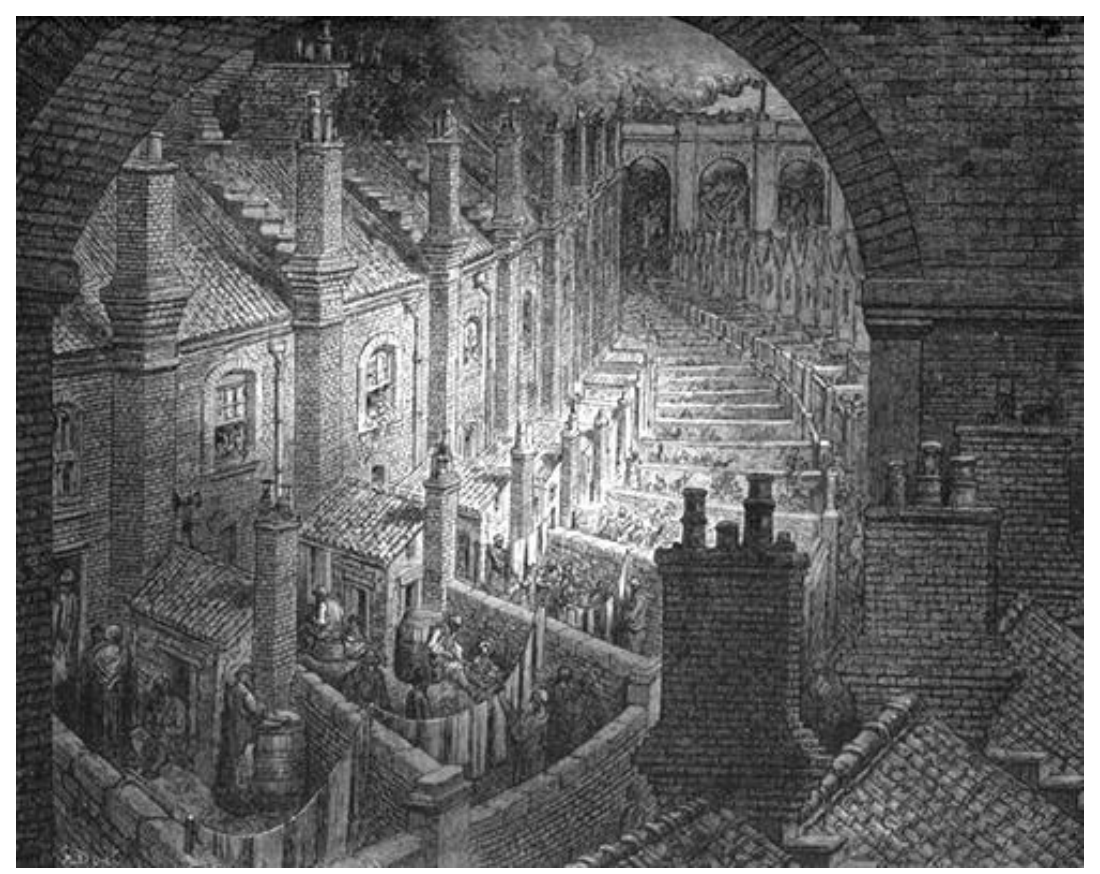

Figura 01: Bairros pobres de Londres. Litogravura de Gustave Doré de 1872. Fonte: BENEVOLO, 1982: 16 .

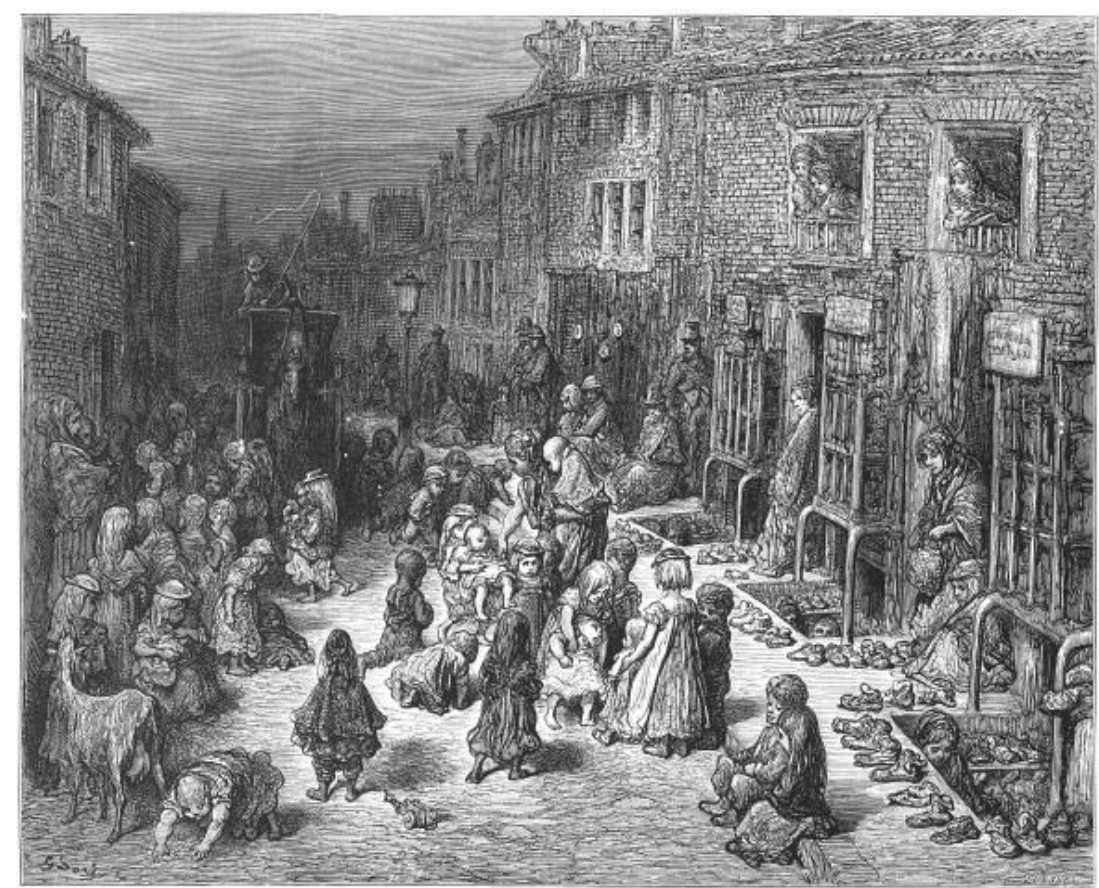

DUDLEY STREET, SEVEN DIALS.

Figura 02: Uma rua de um bairro pobre de Londres (Dudley Street). Litogravura de Gustave Doré de 1872. Fonte: BENEVOLO, 1982: 17. 
Desde as últimas décadas do século XIX a percepção visual do mundo foi marcada pela crescente demanda social por imagens, acelerada pelas exigências geradas a partir da Revolução Industrial, acompanhando as novas formas de utilização de dispositivos técnicos para a produção de imagens. Surge com força o papel da fotografia como forma de representação e análise, tanto social quanto arquitetônico desses espaços. Segundo Kossoy, "o espaço e o tempo implícito no documento fotográfico, subentende sempre um contexto histórico em seus desdobramentos sociais, econômicos, políticos, culturais, etc" (KOSSOY, 2002: 26).

Para Mondenard, a fotografia é considerada um instrumento de expressão visual que transformou a forma do homem em perceber o mundo. Assim, após alguns anos de sua invenção, a fotografia é investida de uma "[...] missão científica, documentária, arqueológica e histórica" (MONDENARD, 1999: 107).

Já Boudelaire, não concebia a idéia de que a obra pudesse ser ao mesmo tempo artística e documental, pois o conceito de arte estava intimamente ligado ao pensamento de que arte, é tudo aquilo que escapa do real (DUBOIS, 1993: 29-30). O contexto da fotografia amparou-se no discurso da mimese, segundo a qual a fotografia era uma reprodução fiel do da realidade, onde o grau de objetividade garantia a credibilidade de tais imagens.

Tanto as interpretações modernas quanto nas imagens de cunho do operariado, precisam de um método como prática trivial de interação, como se a fotografia fosse uma tecnologia de representação neutra. A formação social aparece como aglutinador entre a diversidade de terrenos que une a fotografia aos espaços históricos de representação.

A história determinada social ou socialista, utiliza a fotografia como prova "oculta" da história, criando um imaginário para a sua construção, como, por exemplo, as fotografias da classe operária, das fábricas e das moradias dos operários. Porém nem sempre tem vistas significativas dos que se apropriam dela, nem podem ser interpretadas de uma forma total sobre a multiplicidade de espaços físicos e multiplicidade de práticas sociais.

Se por um lado a fotografia representava uma mimese do real, "já que somente no século XX começou a ser problematizada" ( DUBOIS, 1993: 34), por outro lado, as imagens institucionais no final do século XIX eram produzidas de 
acordo com determinadas normas formais e procedimentos técnicos préestabelecidos, que definiam a conotação que Ihes era dada.

Tagg salienta que a fotografia não deve ser utilizada como uma fonte não problemática, pois se trata de uma prática discursiva. Sua produção cultural, cuja tecnologia varia e depende das instituições que as produzem, as quais dão legibilidade somente dentro dos usos específicos. As formas de poder que se aplicam às práticas de representação, utilizavam artifícios escusos, intencionais ou não, para dar o sentido a fotografia que Ihes era conveniente.

Assim aparece pela primeira vez a utilização da fotografia como documento de comprovação das péssimas condições de higiene do bairro operário de Quarry Hill, em Leeds, Inglaterra. Estas fotografias foram utilizadas no julgamento para demolição das casas dos operários pelo Parlamento inglês ${ }^{2}$, em Londres, em 1901.

A falta de planejamento urbano, as precárias condições de higiene, a falta de ventilação e sol nas estreitas ruelas na zona de Quarry, gerou preocupação pública quanto ao alto índice de mortalidade. Os problemas geraram uma série de investigações governamentais e privadas, que classificaram Leeds com a pior qualidade de vida já vista até então.

As várias medidas de mudanças em Leeds, tomadas pela câmara e pelo parlamento, não tiveram apenas como fator principal de preocupação a difusão de epidemias, mas também um jogo de interesses financeiros pela campanha na demolição de Quarry Hill. Cabe frisar agora que tais medidas representaram um marco em relação a análise das fotografias, que tiveram papel decisivo no julgamento dessas lutas.

Com as mudanças significativas no campo do conhecimento, das tecnologias e de suas representações ao longo do século XIX, assim como, o estudo de estatística, e do censo social, a fotografia foi assumida, como meio de registro e publicidade dessas novas técnicas. Surge a figura do doutor James $\mathrm{S}$. Cameron, que fazia parte da vanguarda de informação sanitária da época, que se identificava com técnicas avançadas que buscavam publicidade para moldar a opinião pública.

\footnotetext{
${ }^{2}$ Câmara dos Comuns e Câmara dos Lordes.
} 
Para o julgamento da demolição em larga escala das moradias insalubres, J. Cameron apresentou fotografias cuidadosamente selecionadas sobre as péssimas condições sanitárias do bairro, tiradas pelo departamento sanitário de Leeds entre os anos 1896 e 1901. Tanto a escolha das imagens como a sua ordenação, foram planejadas com o propósito de refutar toda e qualquer argumentação contrária ao projeto. Ele era um defensor do plano de erradicação das habitações insalubres de Quarry Hill, insistia na denúncia da falta de ar e ventilação dos bairros como motivo principal da propagação de doenças. Essas idéias eram demonstradas através de um ideário "purista", vazio de presença humana, como é verificado na análise de suas fotos.

No caso em questão, as fotografias foram utilizadas como elemento de prova, registro de que as zonas mostradas eram realmente insalubres e precisavam ser erradicadas. Sua apresentação foi seguida por uma detalhada exposição descritiva, que buscava direcionar o olhar do receptor e transmitir um significado às imagens. Ainda assim, J. Cameron não podia controlar por completo o significado das fotografias, já que elas permanecem sempre relativamente abertas a diversas possibilidades de interpretação. Isto é possível porque nós interpretamos as imagens por meio de um repertório cultural próprio, particular..

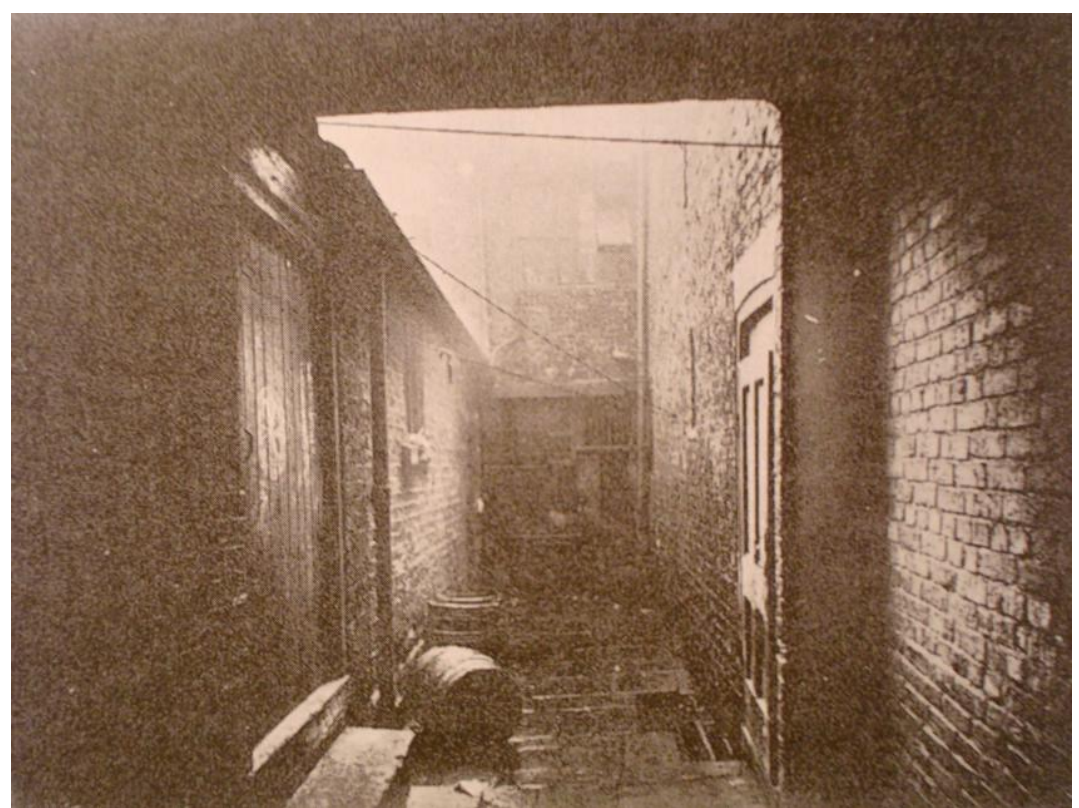

Figura 03: Fotografo desconocido. Pátio ao leste de Bridg Street, em Photographs of Properties of Petitioners in the Quarry Hill Unhealthy Area (Fotos de propriedade de demandantes de la zona insalubre de QuarryHill), 1901. (University of Leeds, Brotherton Library). Fonte: TAGG, 2005: 180 . 
Em uma comparação com as gravuras de Doré, as fotografias apresentadas também tinham como característica tonalidades escuras, porém apresentavam espaços desabitados, sem a presença humana, ao contrário das gravuras. Nas fotos foram retratados edifícios mal construídos, com pavimentos defeituosos; espaços sujos, anti-higiênicos e mal ventilados. Cameron Inúmeras vezes, afirmou ter encontrado dificuldade para captar imagens na região, já que as "ruas e passagens eram tão escuras e estreitas, os interiores tão apertados e fúnebres, que sequer era possível fazer fotografias ali" (TAGG, 2005: 194). Analisando as fotos é perceptível ver além dessas questões, a falta de perspectiva e a pouca distância que as fotos precisavam ser tiradas, agravava a sensação de opressão do lugar. A sujeira causada pela fumaça que se encontrava incrustada nas paredes dos edifícios, aumentava essa ambiência hostil.

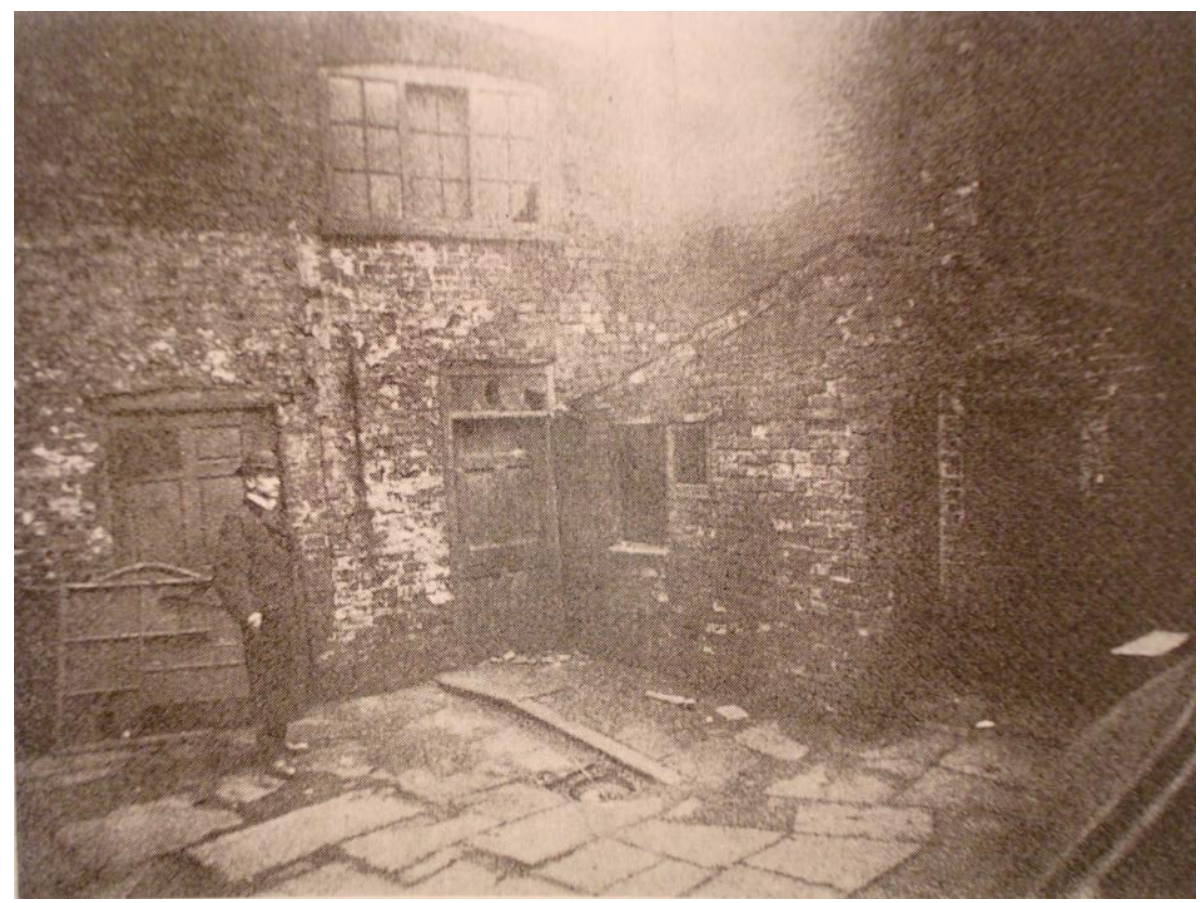

Figura 04: Fotógrafo desconhecido. Pátio junto a St Peter's Square, no 79 del Plan, incluída en City Of Leeds, Insanitary Ares, 1896. (University of Leeds, Brotherton Library). Fonte: TAGG, 2005: 160. 


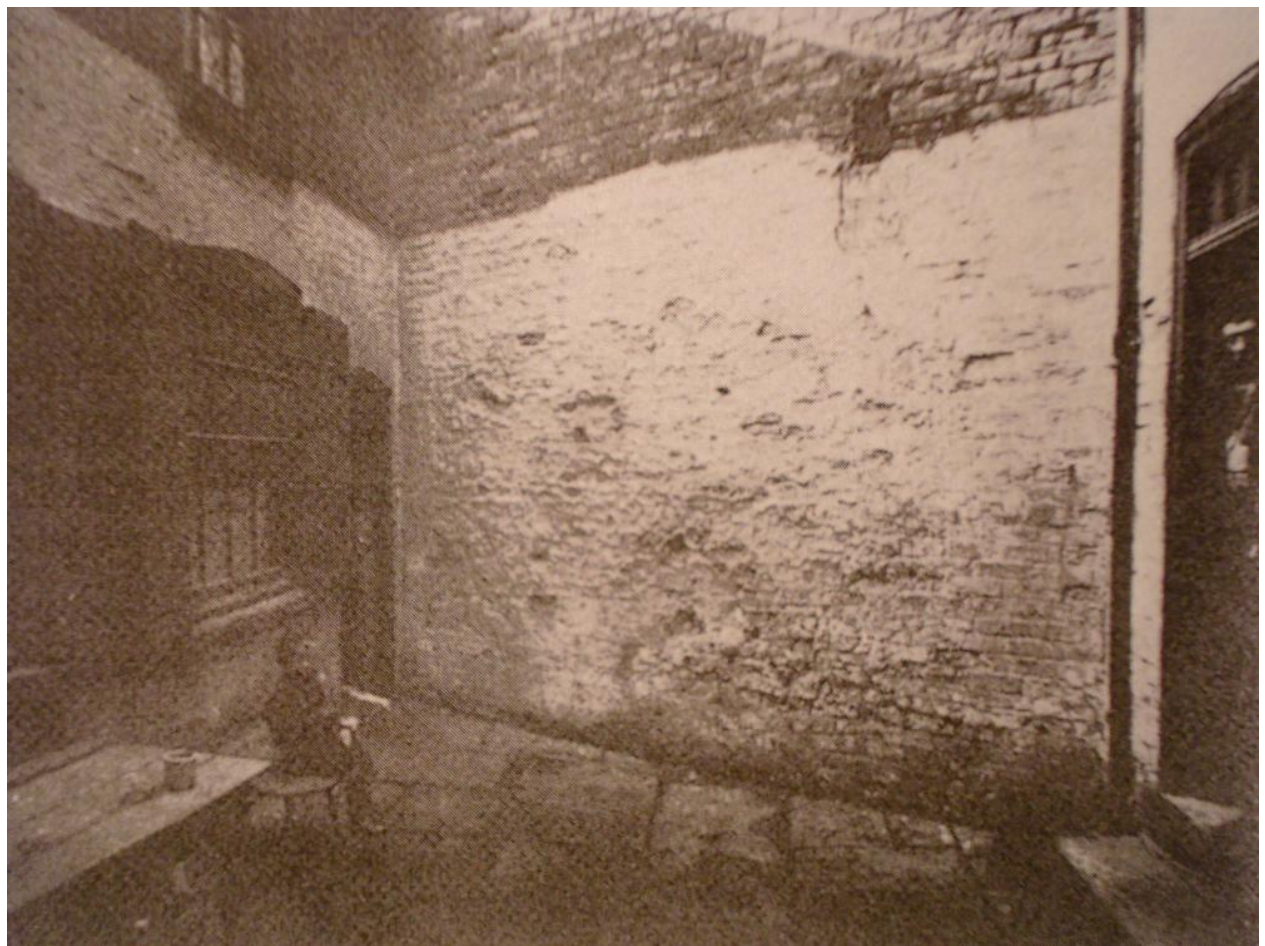

Figura 05: Fotógrafo desconhecido. Pátio exterior de Harrison's Buildings, em City Of Leeds Insanitary Áreas (Zonas insalubres de la ciudad de Leeds), 1896. (University of Leeds, Brotherton Library). Fonte: TAGG, 2005: 188

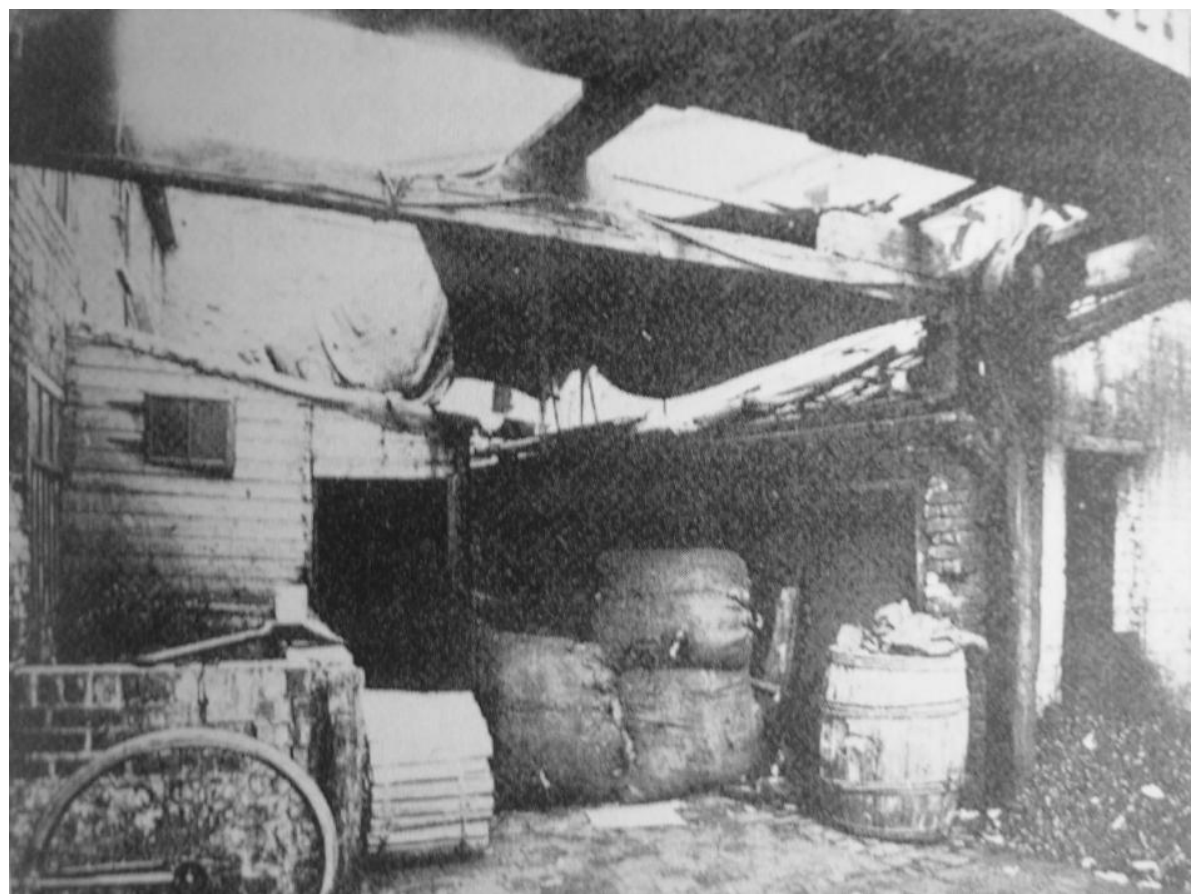

Figura 06: Fotógrafo desconhecido. Pátio de uma fabrica de papel, no Este, em City Photographs of Properties of Petitioners in the Quarry Hill Unheaalthy Área (Fotos de propriedade de demandantes de la zona insalubre de Quarry Hill, 1901). (University of Leeds, Brotherton Library). Fonte: TAGG, 2005: 191. 


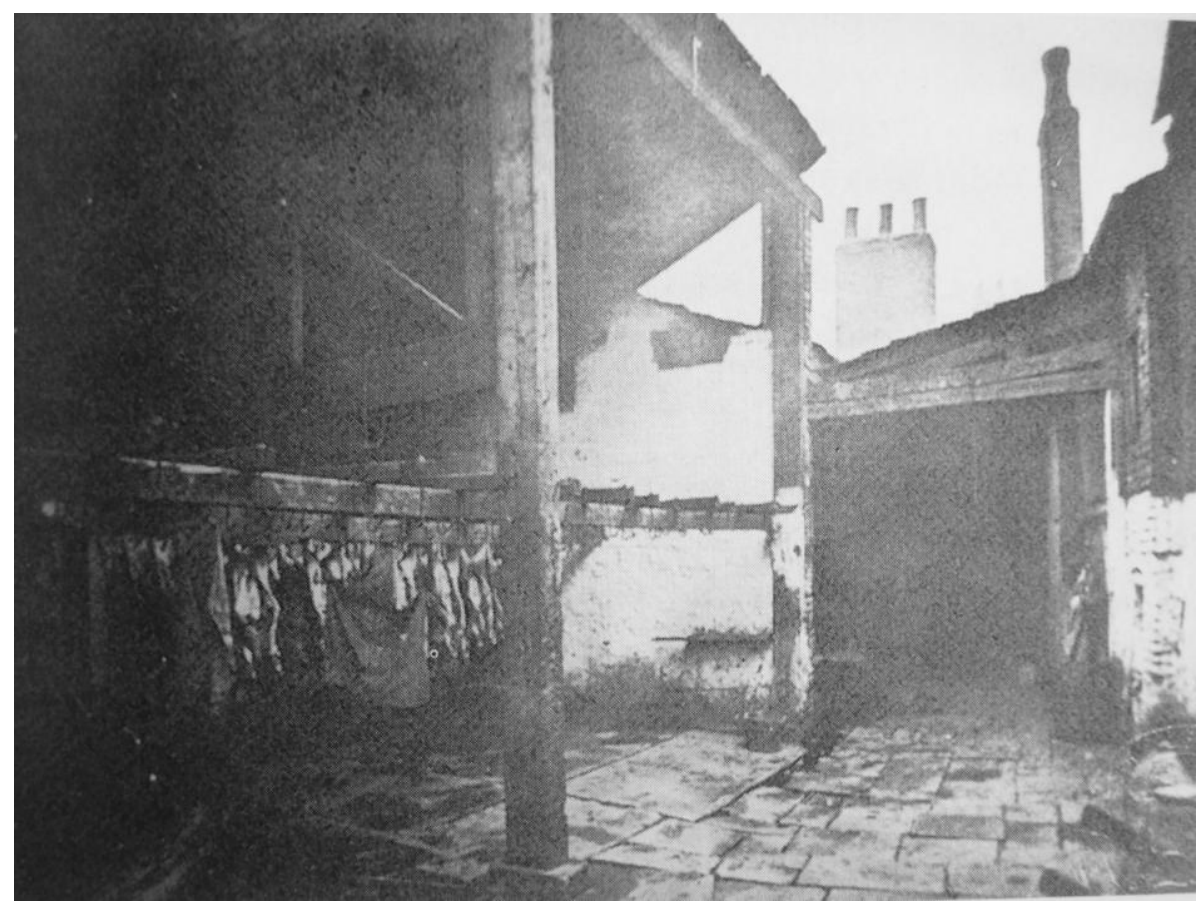

Figura 07: Fotógrafo desconhecido. Vista 13: Interior de Higgins'Yard. A vista fala por si mesma, em Report of Ballard to the local Government Board, etc. [...] upon the Slaughter-Houses and Slaughther-Yards in the Borough, and as to the Estabillisment of Public Abattoir, 28 de Junio de 1880. (Leeds City Libraries, Local History Departament). Fonte: TAGG, 2005: 191.

A falta da presença humana nas fotografias contribui para um olhar desumano, amenizando a intenção da demolição e do desalojamento. Estava em jogo neste caso, a legitimação da fotografia como expressão da realidade e a tentativa de estabelecer um significado favorável à erradicação das moradias insalubres do bairro de Quarry Hill. Segundo Dubois, esse tipo de imagem se configura dentro da categoria de transformação do real. Conforme ele cita os escritos do livro Film as art de Rudolf Arnheim, onde ele propõe as diferenças que a imagem apresenta com relação ao real, que se encaixam neste caso:

[...] em primeiro lugar, a fotografia oferece ao mundo uma imagem determinada ao mesmo tempo pelo ângulo de visão escolhido, por sua distância do objeto e pelo enquadramento; em seguida bidimensional e, por outro lado, todo o campo das variações cromáticas aa um contraste branco e preto; finalmente isola um ponto preciso do espaço-tempo e é puramente visual, excluindo qualquer outra sensação olfativa ou tátil. Como se vê, tal desconstrução do realismo fotográfico baseia-se por inteiro numa observação de técnica fotográfica e de seus efeitos perceptivos (DUBOIS, 1993: 38). 
Não há informações sobre a autoria das fotografias. Muito provavelmente não foi obra de apenas uma pessoa. No entanto, a questão da autoria não se encerra na descoberta de quem "apertou o botão", dado que no caso em questão, as fotografias foram tiradas sob a supervisão do departamento sanitário de Leeds e do próprio J. Cameron em pessoa.

Em nenhum momento o departamento sanitário foi acusado de manipular deliberadamente as fotografias através de retoques e recortes, ou através do pouco tempo de exposição das placas para aumentar o aspecto sombrio das imagens. Tampouco, se questionou se fotografias eram verdadeiramente expressões da realidade. O apontamento das limitações da fotografia poderia ter atuado como contrapeso aos argumentos de J. Cameron. Contudo, no período em que o caso foi julgado pelo Parlamento inglês, em 1901, o debate referente às metodologias de análise das fotografias ainda não havia sido implementado.

Os parlamentares acabaram convencidos da legitimidade das imagens, aceitando a leitura de J. Cameron sobre as péssimas condições de higiene do baiiro. Acabou, deste modo, perdurando não um documento neutro da realidade, e sim uma apresentação oficial minuciosamente elaborada pelo departamento sanitário de Leeds, que tinha como objetivo erradicar as moradias insalubres de Quarry Hill.

A urgência das medidas saneadoras e urbanísticas são tomadas por toda a Europa, abrem-se ruas, e criam-se várias propostas de projetos para os aglomerados dos trabalhadores da indústria. Essas transformações se dão também no campo das imagens, novas formas de representação desse ideário de habitar, dentro de uma ordenação planejada. A este respeito Almada descreve que:

Paralelamente, as mesmas idéias - 'isolamento' e 'visibilidade' - foram aplicadas, agora com sucesso, no plano urbanístico. Através de operações de saneamento, alargamento e abertura de ruas e avenidas, renovação e modernização urbana, ou seja, de modo não-explícito, implantou-se a segregação das classes sociais no espaço da cidade. Os pobres foram isolados em guetos ou expulsos para cidades satélites e conjuntos periféricos. As cidades tornaram-se 'transparentes', física e socialmente: a cada espaço correspondendo um status - ou posição social - e a cada status correspondendo um espaço (ALMADA, 1986: resumo). 
A recriação dos princípios de divisão social do trabalho, extrapolam o ambiente fabril, e se materializam na espaço e na arquitetura, utilizando-se dela como testemunho de um quadro sócio-econômico através da história.

A partir do momento em que as medidas começaram a ser tomadas, as imagens passaram a ter um cunho de representação da resolução do problema, e não mais como caráter de denúncia à partir do retrato do real. As imagens a partir de então passam a ter outra função, a de representatividade dos novos planos saneadores.

As idéias de isolamento e visibilidade, foram aplicadas com sucesso, no plano urbanístico. Através de operações de saneamento, alargamento e abertura de ruas e avenidas, renovação e modernização urbana, ou seja, de modo nãoexplícito, implantou-se a segregação das classes sociais no espaço da cidade. Os trabalhadores das fábricas foram isolados em conjuntos periféricos. "As cidades tornaram-se transparentes, física e socialmente: a cada espaço correspondendo um status - ou posição social - e a cada status correspondendo um espaço" (ALMADA, 1986: resumo).

Após a revolução de 1848, entram em crise tanto os movimentos de esquerda, quanto os liberais, assumindo o poder de direita. "A burguesia vitoriosa, estabelece o novo modelo de cidade, no qual os interesses dos vários grupos dominantes, empresários e proprietários, estão parcialmente coordenados entre si" (BENEVOLO, 2003: 573). Aparecem várias propostas de projetos de vilas operárias, cuja prática da construção por empresas de moradias para seus operários difundiu-se largamente a partir do início do século XIX. Seguindo o modelo inglês, essa prática se disseminou primeiramente por toda Europa, e mais tarde em outros países inclusive no Brasil.

Partindo da idéia de que Arquitetura é a imagem do espaço construído, é possível fazer sua leitura através da análise morfológica de tipologia através do estudo de plantas e desenhos urbanísticos. Segundo Roques "o espaço não é dado a priori, é algo construído, um produto. O espaço como forma é uma construção feita pelo homem" (ROQUE, 1997: 30).

Conforme Foucault, "a disciplina é uma forma de organização do espaço" (FOUCAULT, 1992: XVII), esse conceito se encaixa perfeitamente aos conjuntos de habitações para operários. Dentro da idéia de que a fábrica 
concedia ou alugava habitações aos operários dentro do núcleo fabril, e tinha todo o suporte de serviços e atividades de entretenimento, para que o funcionário não precisasse sair do núcleo, está pré-subtendido que este tinha o controle sobre todas as esferas da vida de seu subordinado.

Tem-se em Platão uma concepção de espaço que inclui os efeitos que o mesmo produz no espectador, mais especificamente, neste caso, o ponto de vista. Da mesma forma, Platão defendeu a unidade, o todo, para ele, seria impossível pensar em unidade tendo que admitir a pluralidade dos pontos de vista. Fazendo a analogia com esta teoria, a repetição dos objetos em série, temse um ponto de vista igualitário, onde os operários não se distinguem uns dos outros.

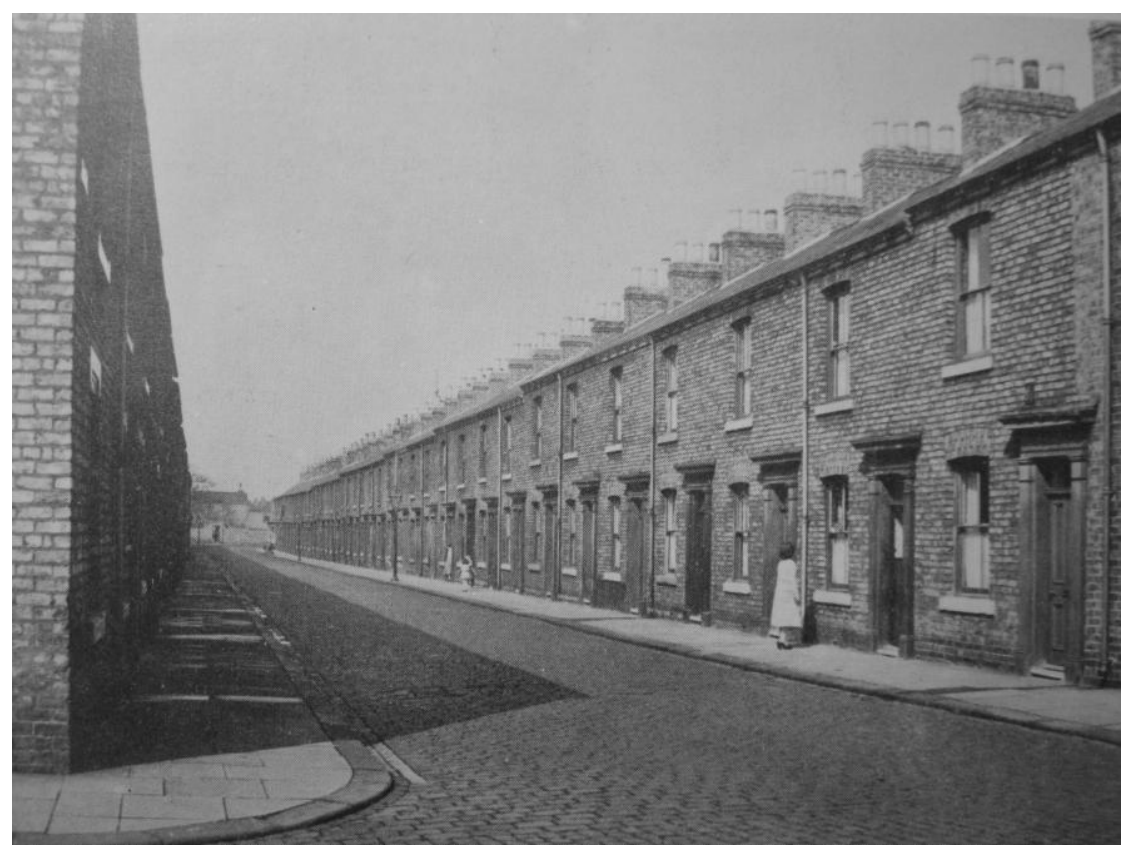

Figura 08: Os bairros periféricos ingleses, construídos conforme os regulamentos de 1875 que previam a uniformidade obsessiva. Fonte: BENEVOLO, Leonardo. História da Cidade: 577. 


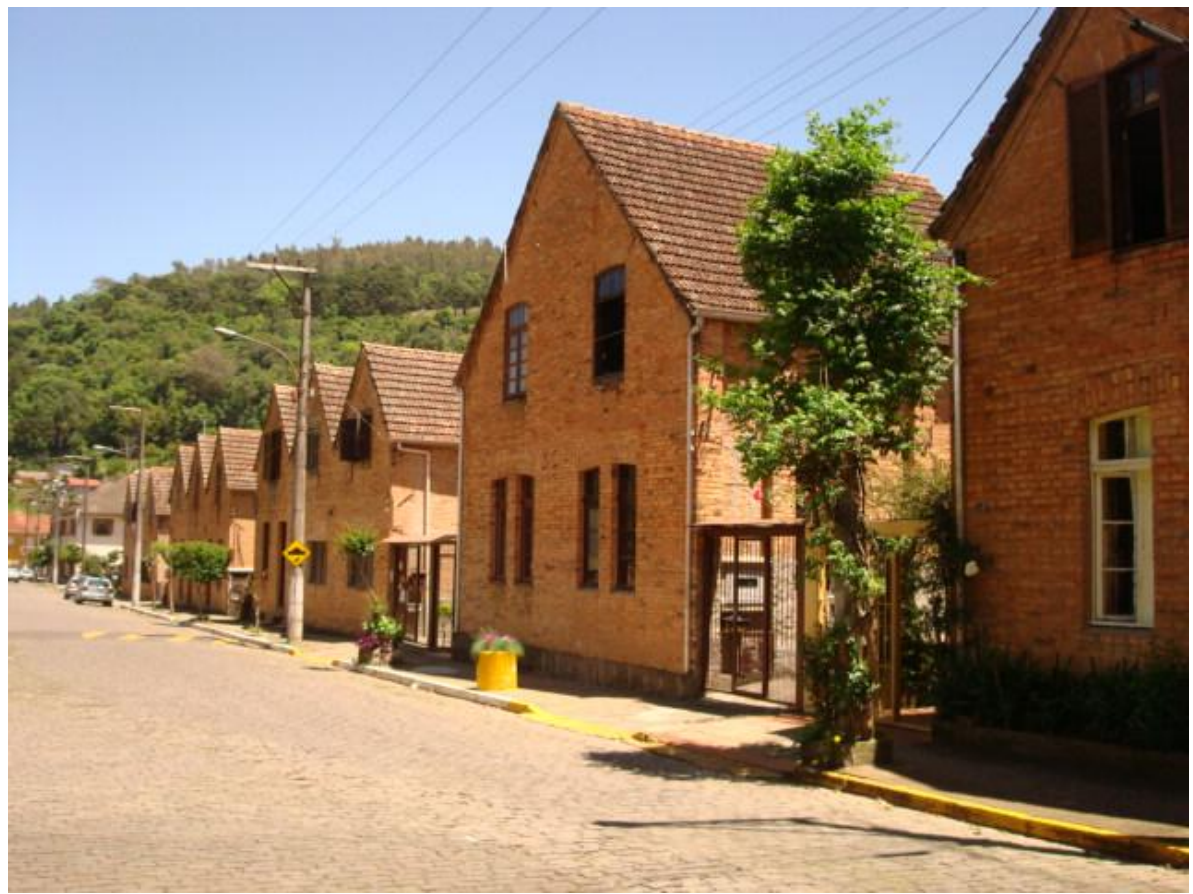

Figura 09: Fachadas da vila operária de Galópolis - Caxias do Sul. Foto: Daniela Ketzer Milano. 2008.

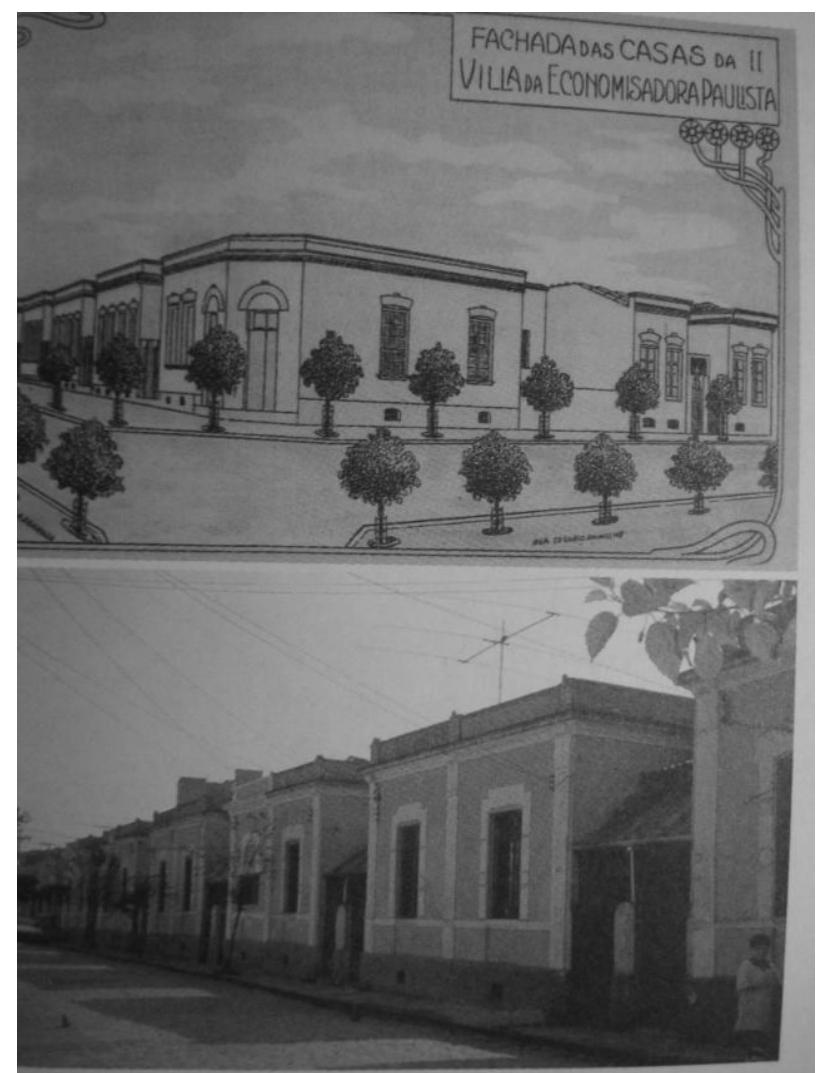

Figura 10: Repetição de fachadas - Vila Particular Economizadora Paulista. Fonte: BONDUKI, 2004: 67. 


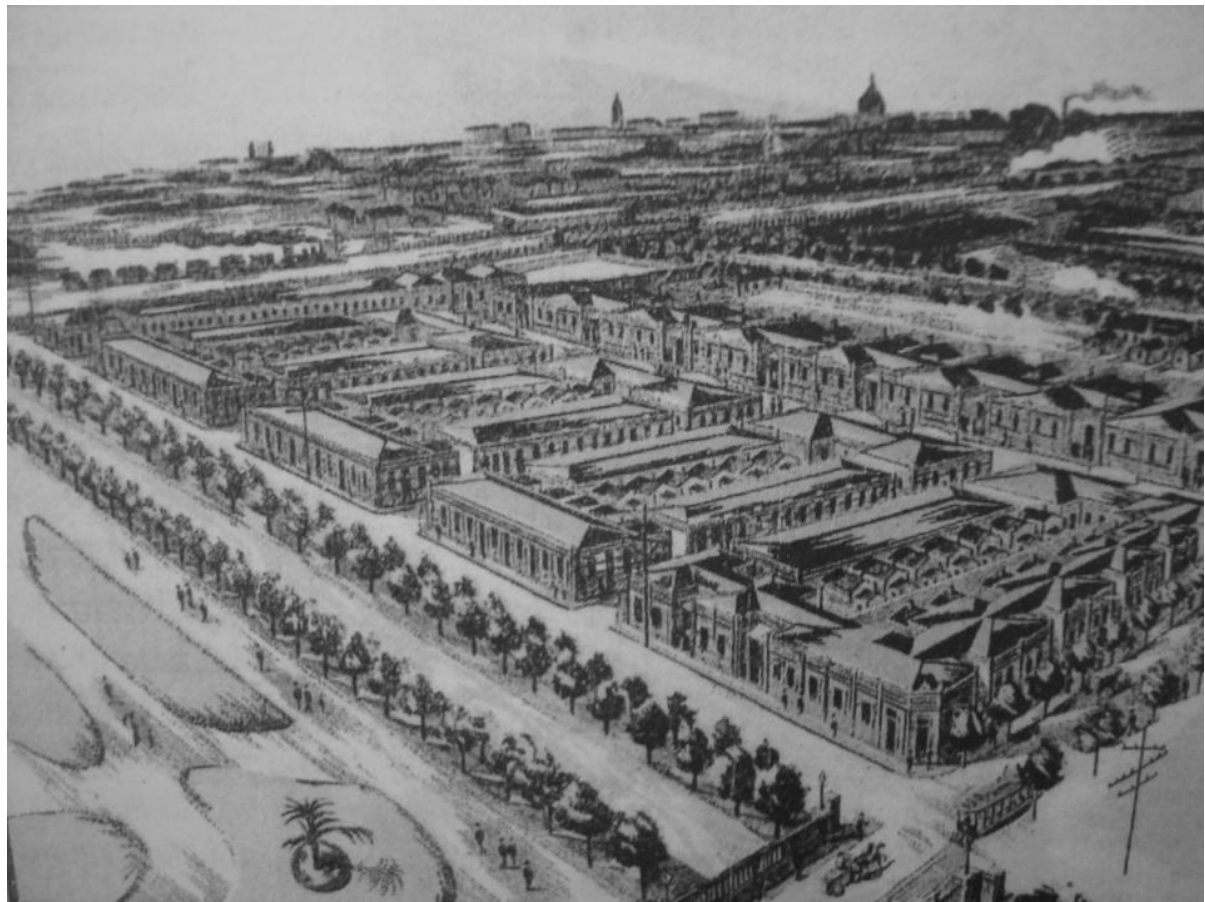

Figura 11: Vista da vila implantada no bairro da Luz - Vila Particular Economizadora Paulista. Fonte: BONDUKI, Nabil. Origens da Habitação Social no Brasil. p.66.

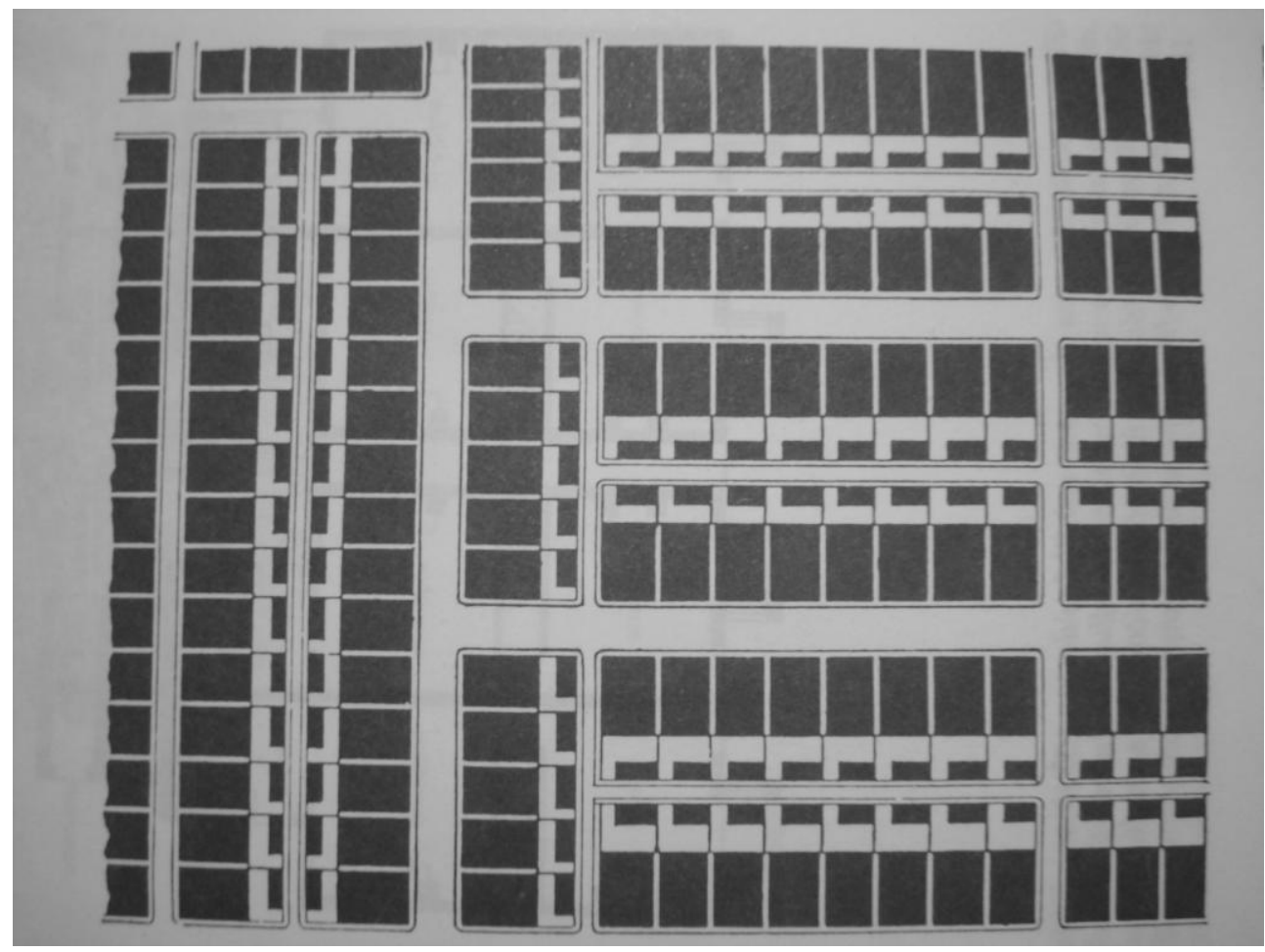

Figura 12: Os bairros periféricos ingleses, construídos conforme os regulamentos de 1875; a vontade de desfrutar o máximo os limites regulamentares produz a uniformidade obsessiva destes bairros. Fonte: BENEVOLO, Leonardo. História da Cidade. p.577. 


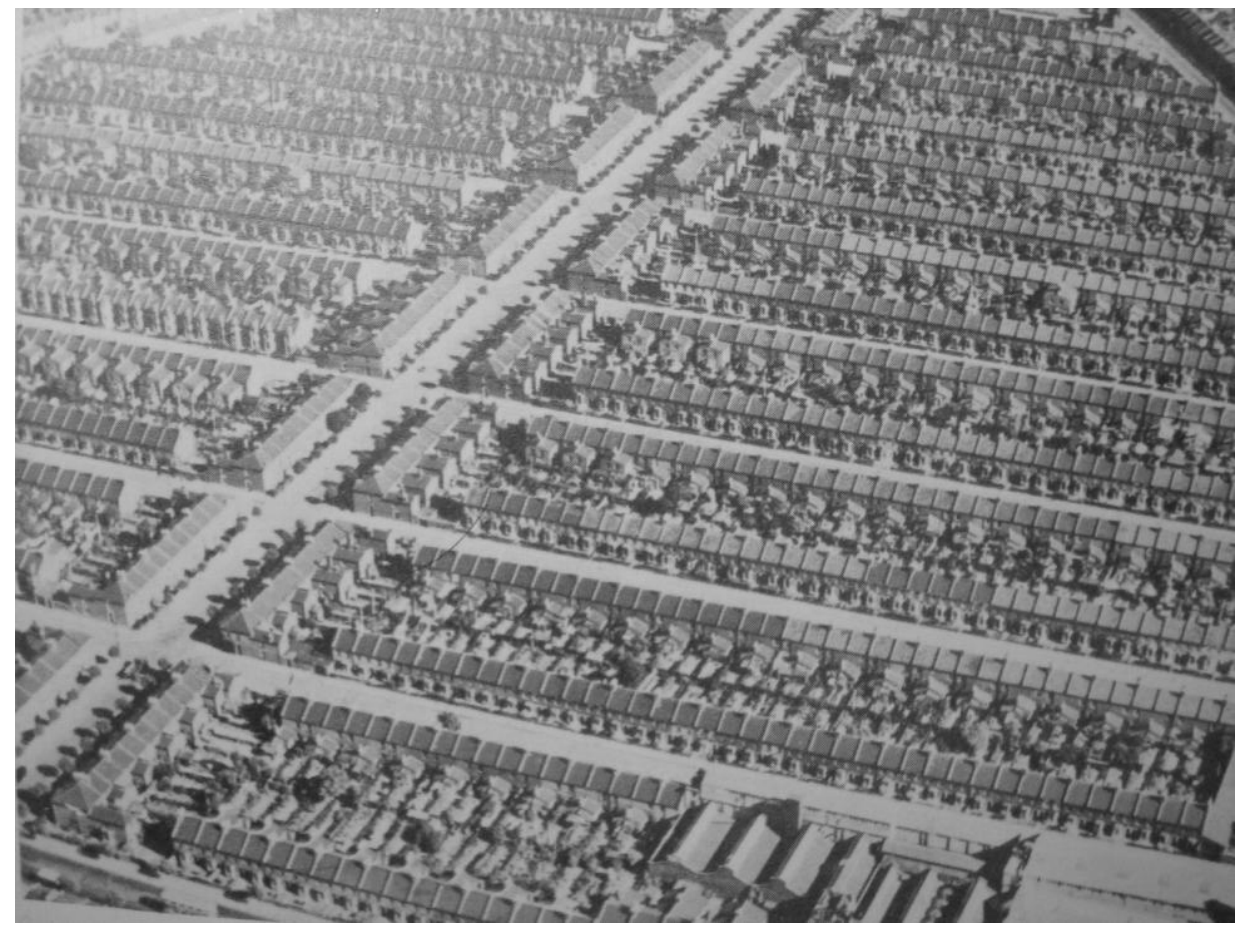

Figura 13: Os bairros periféricos ingleses, construídos conforme os regulamentos de 1875; a vontade de desfrutar o máximo os limites regulamentares produz a uniformidade obsessiva destes bairros. Fonte: BENEVOLO, Leonardo. História da Cidade. p.577.

A implantação desses modelos seguia a premissa do traçado linear, uniforme. O centro da hierarquia era a fábrica colocada como núcleo principal. $A$ segunda esfera dessa hierarquia se dava pela localização das casas dos mestres e contra-mestres, os quais representavam "o conceito do olhar invisível proposto por Bentham no Panóptico, segundo o qual é permitido ver tudo , permanentemente sem ser visto" (NORRO, 1997: 54).

O modelo da "vila operária" passa a ter um rigoroso regime de ordenação, de acordo com Reis:

A percepção de ordem na composição da forma arquitetônica, que implica percepção de unidade de uma estrutura na organização dos elementos compositivos, provoca uma reação satisfatória ao estímulo e é condição para uma percepção aproximada da forma. No processo de percepção visual, o olho seleciona e combina elementos, procura formas mais simples e tenta integrar vários elementos do campo visual em unidades reduzidas (WEBER, 2002: 17). 


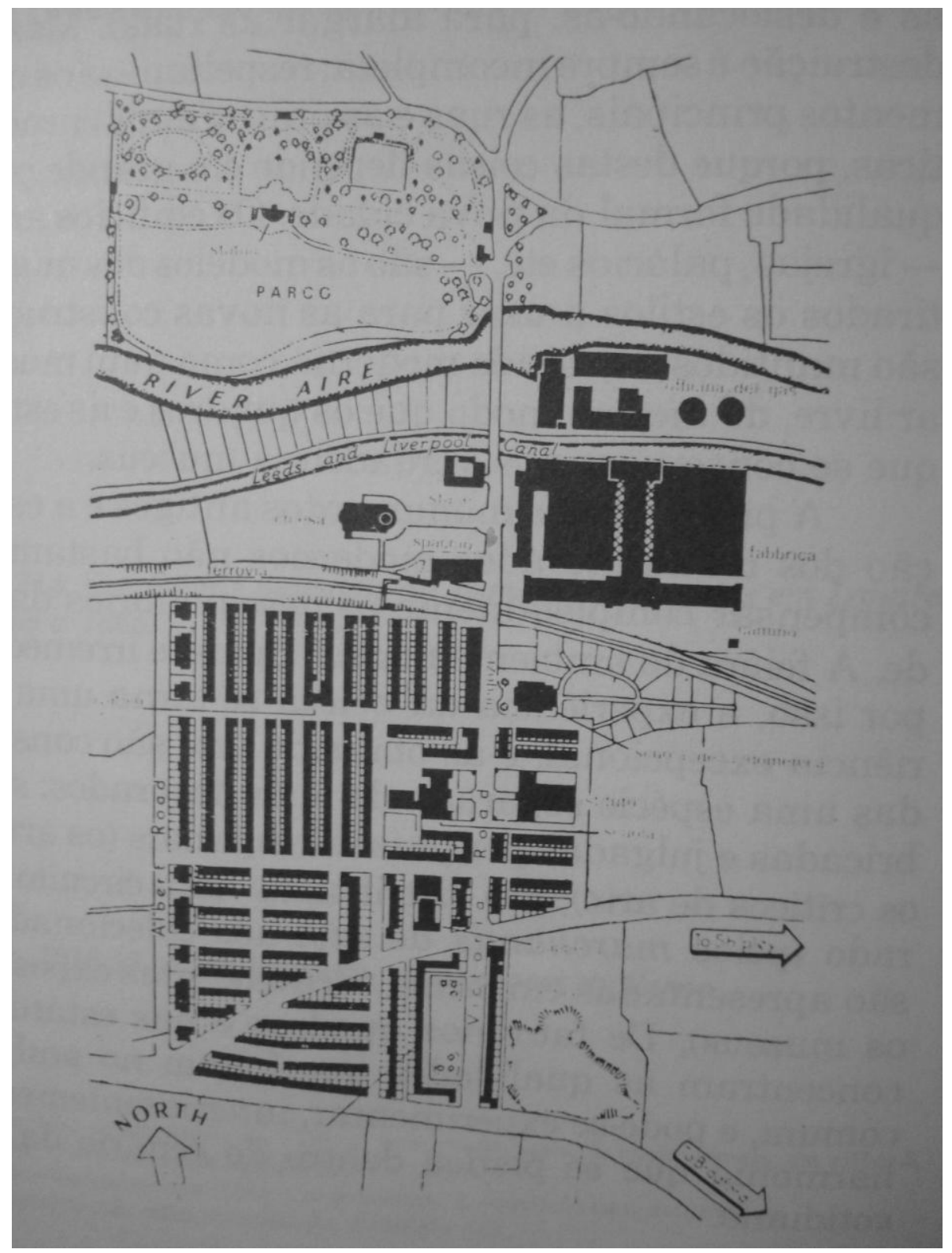

Figura 14: Os bairros periféricos ingleses, construídos conforme os regulamentos de 1875; a vontade de desfrutar o máximo os limites regulamentares produz a uniformidade obsessiva destes bairros. Fonte: BENEVOLO, Leonardo. História da Cidade. p.577.

O conjunto habitações para operários, fábrica e infra-estrutura e serviços, são elementos formadores de uma malha urbana. As vilas operárias tinham um sistema quase autônomo, tudo que se precisasse tinha ali, as empresas promoviam atividades de diversão e entretenimentos nos poucos momentos que os funcionários tinham de folga. Estes organismos passaram a ser "cidades dentro das cidades". 


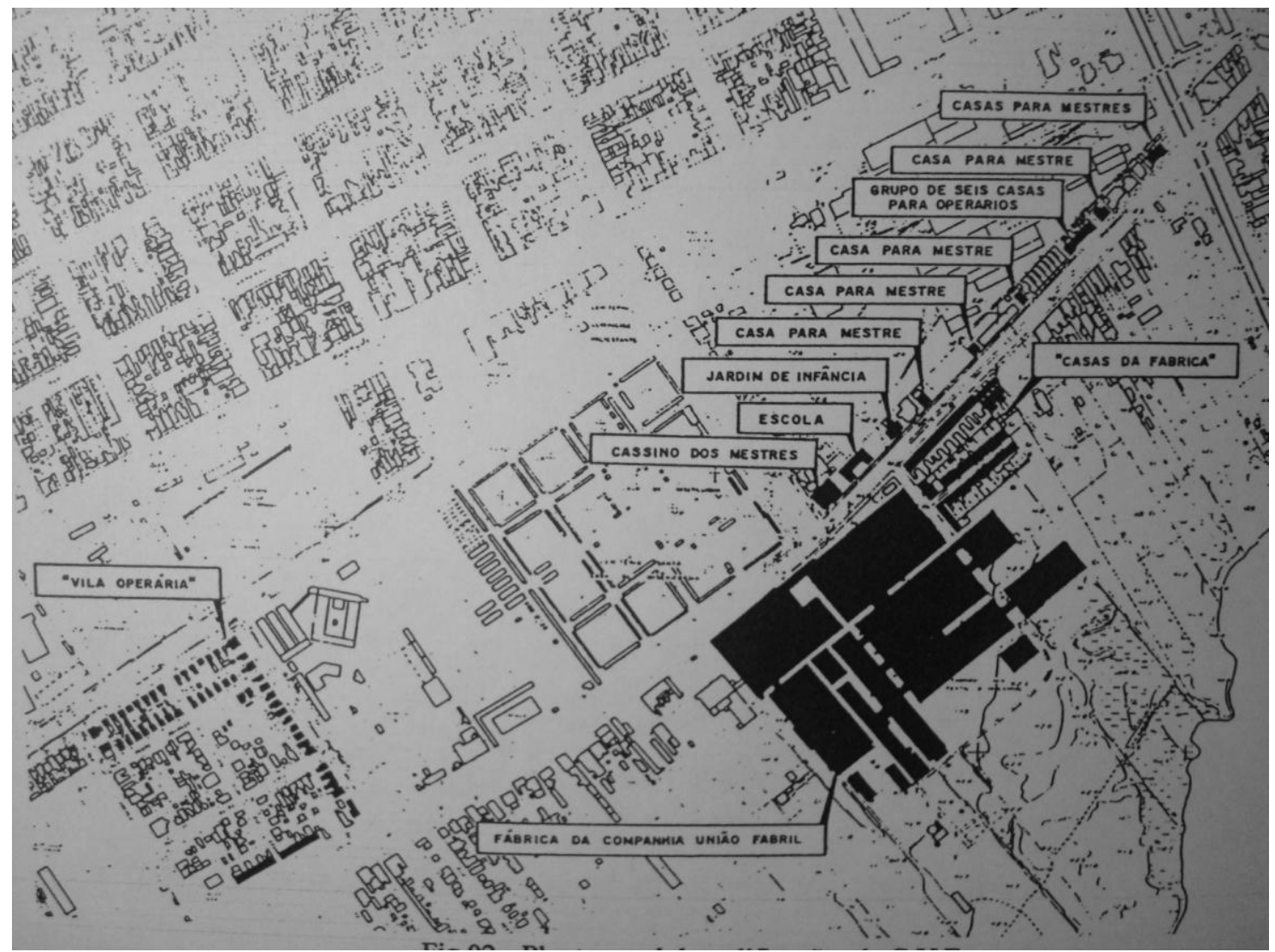

Figura 15: Implantação das edificações da vila operária na malha urbana da cidade de Rio Grande

- Complexo União Fabril Rheingantz. Fonte: NORRO, Júlio Ariel Guigou. A vila operária na República Velha: o caso Rheigantz - conceito e materialidade. p.160.

\section{CONCLUSÃO}

Foi possível concluir ao longo do trabalho, que existiram três momentos na produção das imagens das habitações operárias. A primeira representou um manifesto, teve a forma de denúncia descritiva, uma literária e a outra em forma de gravuras, que representavam as primeiras através do desenho. A segunda, utilizou as imagens fotgráficas, como representação documental de prova para o julgamento para erradicação das zonas insalubres. E o terceiro tipo de imagem, aparece como um elemento de resolução do problema, um plano de soluções, neste contexto aparece a análise dos projetos e da arquitetura construída.

Assim sendo, através da análise das imagens deste trabalho, pode-se chegar à conclusão da importância de investigação do contexto de sua criação das determinantes sócio-culturais, das intenções dos produtores da imagem, do fotógrafo e do contratante, e do circuíto social que essas imagens circulam. 
Portanto, para um estudo mais aprofundado dentro do tema sociológico em questão, deve-se estar atento para que estas fontes não sejam interpretadas de forma equivocada, se faz necessária a realização de uma minusiosa análise do contexto ao qual foram produzidas.

\section{REFERÊNCIAS BIBLIOGRÁFICAS}

BeneVolo, Leonardo. Diseño de la Ciudad - 5. El ambiente de la Revolución Industrial. 3. ed. Barcelona: Editora Gustavo Gilli S.A, 1982.

1995.

A cidade na História da Europa. 1. ed. Lisboa: Editorial Presença,

. História da Cidade. 3. ed. dois reimpressão. São Paulo: Editorial Perspectiva, 2003.

BONDUKI, Nabil. Origens da habitação social no Brasil. 4. ed. FAESP - São Paulo: Editorial Liberdade, 2004.

CHEVALIER, Louis. Labouring classes and dangerous classes in Paris during the first half of the nineteenth century. Trad. F. Jellinek. New Jersey, Princeton University Press, 1973, p. 155-156. In: AZEVEDO, Ricardo Marques de. Uma Idéia de Metrópole no Século XIX. Rev. bras. Hist. vol.18 n.35 São Paulo 1998.

CORREIA, Telma de Barros. De Vila Operária a Cidade-Companhia: Aglomerações criadas por empresas no vocabulário especializado vernacular. In: Revista Brasileira de Estudos Urbanos e Regionais -. São Paulo: Publicação da Associação Nacional de Pós-Graduação e Pesquisa em Planejamento Urbano e Regional, 2001, v. 4, p. 83-96.

CORREIA, Telma de Barros. GHOUBAR, Khaled. MAUTNER, Yvone Brasil, suas Fábricas e Vilas Operárias. In: Revista do Programa de Pós-Graduação em Arquitetura e Urbanismo da FAUUSP -. São Paulo: Apoio CNPq e Capes, 2006, n.20, p. 10-32.

DUBOIS, Phelippe. Da semelhança ao índice. In: O ato fotográfico e outros ensaios. Campinas: Papirus, 1993.

ENGELS, Friedrich. A questão da habitação. Belo Horizonte: Aldeia Global Livraria e Editora LTDA, 1979. 
1985.

A situação da classe trabalhadora na Inglaterra. São Paulo: Global,

FOUCAULT, Michael. Vigiar e punir. Petrópolis-RJ: Vozes, 1991.

. Microfísica do poder. Rio de Janeiro: ed. Graal, 1992. p. XVII.

KIRSCHENMANN, Jörg C. Vivienda y espacio Público. Rehabilitación urbana y crecimiento de la ciudad. Barcelona: Editora Gustavo Gilli S.A, 1985.

KOSSOY, Boris. Construção e desmontagem do signo fotográfico. In:_. Realidades e Ficções na Trama Fotográfica. São Paulo: Ateliê Editorial, 2002.

LIMA, Solange Ferraz de; CARVALHO, Vânia Carneiro de. Fotografia e Cidade: da razão urbana lógica do consumo: álbum da cidade de São Paulo, 18871954. Campinas, SP:Mercado das Letras; São Paulo: Fapesp, 1997.

MILANO, Daniela Ketzer. Vilas Operárias: o caso de Galópolis. Monografia de conclusão de Pós Graduação em nível de especialização em Arquitetura Brasileira e Patrimônio Histórico no Brasil. Faculdade de Arquitetura e Urbanismo PUCRS. Porto Alegre, 2007.

. Uma vila operária na colônia italiana: o caso Galópolis (19061941). Porto Alegre: Dissertação de Mestrado do Curso de Pós Graduação em História Ibero Americana da PUCRS, 2010.

MONDENARD. Anne de. A Emergência de um Novo Olhar sobre a Cidade: as fotografias urbanas de 1870 a 1918. In: Projeto História: espaço e cultura. no 18, 1999.

MONTEIRO, Charles. Imagens sedutoras da modernidade urbana: reflexões sobre a construção de um novo padrão de visualidade urbana nos anos de 1950. In: Revista Brasileira de História ANPUH, no 53, vol. 27, 2007, p. 159-176.MORRIS, A.E.J. História de la forma urbana. 5. ed. Barcelona: Editora Gustavo Gilli S.A, 1995.

MUMFORD, Lewis. A cidade na história - suas origens, transformações e perspectivas. São Paulo: Martins Fontes, 1982.

NORRO, Júlio Ariel Guigou. A vila operária na República Velha: o caso Rheigantz - conceito e materialidade. Dissertação de Mestrado, área de concentração em Arquitetura do curso de Mestrado em Arquitetura da UFRGS, Porto Alegre, 1997. 
ROQUE, Georges. La Pragmática del Espacio In: Arte y Espacio. México: Universidad Nacional Autônoma de México- Instituto de Investigaciones Estéticas, 1997.

ROSSI, Aldo. A Arquitetura da Cidade. 2. ed. São Paulo: Martins Fontes, 2001.

TAGG, John. El peso de la Representación. Barcelona: Editorial Gustavo Gili S.A., 2005.

VIANNA, Mônica Peixoto. Habitação e modos de vida em vilas operárias. Dissertação de Mestrado, USP, São Paulo, 2004.

WEBER. R. On teh Aesthetics of Architecture, A Phychological Approach to the Structure and the Order of Perceived Architectural Space. Avebury, Aldershhop, England, 1995. In: REIS, Antônio T. Repertório, Análise e Síntese: Uma Introdução ao Projeto Arquitetônico. 1. ed. Porto Alegre: Editora UFRGS, 2002. 